\section{RETROSPECTIVE STUDY ON SUICIDAL CASES AT SIR SALIMULLAH MEDICAL COLLEGE MORGUE HOUSE IN THE YEAR 2008}

Tejendra Chandra Das ${ }^{1}$, Mostaque Rahim ${ }^{1}$, Md. Nazmul Hoq ${ }^{2}$, Mosahef Uddin Ahmed ${ }^{3}$, Sharmin Yasmin ${ }^{4}$, Tamam Rahman Sarker ${ }^{5}$

\begin{abstract}
Suicide is one of the commonest causes of unnatural death in the world. The number of suicide is increasing over the period of time. Our research focused on a number of factors associated with the occurrence of suicide, these includes- age, gender, religion, cause of death, modes of death. A total of 95 cases of suicide were studied in Sir Salimullah Medical College morgue house in the year 2008. The victims were composed of 33 males (34\%) \& 62 females (66\%) and the age group of 21-30 years was the most common, which indicates occurrence of suicide is more common in young females. Of 95 cases, the most common cause of death was due to asphyxia, 88 cases (92\%). Other cases include respiratory failure- 3 cases (3\%), hemorrhage $\&$ shock- 4 cases (5\%). In the discrimination of cause of death, we obtained information on victims \& witness as well as investigating the scene $\&$ post mortem examination of the victim.
\end{abstract}

\section{Introduction:}

Suicide means self-murder. This is considered as unlawful act and punishable ${ }^{1}$. This is one of the problems of a constantly increasing importance. This is determined by certain demographic, social, economic, psychological and health aspects of the suicidal acts which can be summarized as: loss of human potential, comparatively high use of the resources of health care - general and specialized, negative psychological influence over individuals, groups, communities and the whole society. In the past, when suicide was taboo according to the society and religion, it was concealed as being the reason for death. This concealment could be due to economic motives. Risk factors includes: Age, sex, marital status, socio-economical status, pre-existing psychological illness. In young age group,

1. Professor \& Head, Dept of Forensic Medicine, Sir Salimullah Medical College, Dhaka

2. Professor \& Head, Dept of Forensic Medicine, Rangpur Medical College

3. Associate Professor \& Head, Dept of Forensic Medicine, Bangladesh Medical College, Dhaka

3. Assistant Professor, Dept of Forensic Medicine, Bangladesh Medical College, Dhaka

4. Professor, Dept of Community Medicine, Bangladesh Medical College, Dhaka

5. Lecturer, Dept of Forensic Medicine, Bangladesh Medical College, Dhaka failure in examination, disappointment in love, are the most common predisposing factor ${ }^{3}$. With the advance in age, with the increase of susceptibility to different diseases, which can lead to a fatal outcome, it becomes more difficult to establish whether the suicidal attempt has caused the death or the person has died of a natural cause. Even the ceasing of the intake of medicines of vital importance is often not accepted as a suicidal attempt ${ }^{6}$. Sex group of committing suicide shows variation in different countries. Regarding marital status; the higher percentage of suicides is with the divorced, followed by the widowed and single people. At the same time the married people show the lower percentage of the suicides ${ }^{6}$.

\section{Objectives:}

- $\quad$ To determine the cause of death

- To determine the socio-demographic profile of victims

- To determine the common age group of suicidal cases.

- $\quad$ To find out the common sex group of suicidal cases.

\section{Materials \& methods:}

A retrospective study was carried out at Dept of Forensic Medicine of Sir Solimullah Medical College (SSMC) with 95 suicidal cases. Purpose sampling was done as sampling technique. Data were collected from the record of the post mortem examination held in SSMC morgue house from January to December 2008. Data were taken manually which included socio-demographic distribution of victims, cause of death \& modes of suicide.

\section{Results:}

Table -I: Socio-demographic distribution of the victims $(n=95)$ :

\begin{tabular}{lcc}
\hline & Frequency & Percentage (\%) \\
\hline A. Age distribution & & \\
Upto 20 years & 36 & 38.15 \\
$21-30 \quad$ years & 43 & 45 \\
$31-40 \quad$ years & 13 & 13.6 \\
$41-50 \quad$ years & 2 & 2.1 \\
Above 50 years & 1 & 1.15 \\
B. Sex distribution & & \\
Male & 33 & 34 \\
Female & 62 & 66 \\
C. Religion & & \\
Muslim & 88 & 92 \\
Hindu & 6 & 7 \\
Unknown & 1 & 1 \\
\hline
\end{tabular}


Table-II: Cause of Death

\begin{tabular}{lcc}
\hline Cause of Death & Frequency & Percentage (\%) \\
\hline Ashphyxia & 78 & 82 \\
Respiratory Failure & 13 & 13.6 \\
Hemorrhage \& Shock & 4 & 4.4 \\
\hline
\end{tabular}

Table-III: Modes of Suicide

\begin{tabular}{lcc}
\hline Modes of Death & Frequency & Percentage (\%) \\
\hline Hanging & 78 & 82 \\
Suspected poisoning & 13 & 13.6 \\
Cut injury & 4 & 4.4 \\
\hline
\end{tabular}

\section{Discussion:}

Suicide is one of the commonest cause of unnatural death in our country as well as in the world. The number of unnatural death due to suicide is increasing day by day. According to retrospective study, suicide in one of the ten leading causes of death in the world, accounting for more than a million deaths annually. ${ }^{2}$ The common causes of suicide in our country are domestic trouble, worries (financial worries mainly), quarrels, failure in examination, disappointment in love $\&$ frustration in life due to various reasons ${ }^{3}$.

In this study 95 cases of suicide were studied in Sir Salimullah Medical College Morgue House in the year 2008.All the cases were analyzed as to age, sex, religion and modes of suicide. According to Age distribution, 36 cases were upto 20 years (38.15\%), 43 cases were between $21-30$ years (45\%). It is observed that highest incidence of suicide occurred in between 21-30 years age group. 13 cases were in 31-40 years age group (13.6\%). In the study it is shown that as the age increases incidence of suicide gradually declines. Out of 95 cases 2 cases were found in between $41-50$ years age group (2.10\%). Above fifty years the incidence of suicide is rare. In our study only one case was found above 50 years (1.15\%). In a present study in India, the largest number of victims were also found in the age group of 21-30years. ${ }^{1}$ But in many other countries of the world like Japan ${ }^{4}$, Ireland ${ }^{5}$, Bulgaria ${ }^{6}$, study showed age group range of 50-70 years was most common.

In the study it is shown that suicidal occurrence in females are more than in males. Out of 95 suicidal cases 62 were females (66\%) \% 33 were male (34\%). But in Japan, during 1995-2005 males were more victimized than female ${ }^{4}$.

Bangladesh is a country where about $90 \%$ of populations are Muslim. So, it is justifiable that Muslims are more victimized than other religion. According to our study out of 95 cases 88 persons were Muslim (95\%), 6 persons were Hindu (7\%) \& 01 person was of unknown religion.

Regarding mode of death Asphyxia is the commonest cause of death in suicide, which is due to hanging. Our study has focused, out of 95 cases, 88 cases were due to hanging (92\%) where cause of death were asphyxia. In India, Hanging \& poisoning constituted the two major modes of suicide. ${ }^{2}$ Cause of death were respiratory failure in 03 persons (03\%) which were due to suspected poisoning and in 04 persons were haemorrhage $\&$ shock (05\%) which were due to suicidal cut throat. In Japan, study showed that $49 \%$ of suicide occurred by cut throat wound, stab wound in the chest $\&$ by cut injury in the flexor side of wrist ${ }^{4}$.

\section{Conclusion:}

Our study focused that the common age group of suicides are between 21-30 years age group \& in relation to gender females are more victimized in our country. The predisposing factors are domestic trouble, worries (financial worries mainly), quarrels, failure in examination, disappointment in love \& frustration in life due to various reason. We can try to minimize the incidence of suicide by counseling the probable victims at family level, maintaining good relation between family members and giving education at the educational institute to maintain sound mental health.

\section{Reference:}

1. Textbook of Forensic Medicine and Toxicology, by Nageshkumar G Rao, First Edition

2. Sachidananda Mohanty, Geeta Sahu, Manoj Kumar Mohanty, and Manju Patnaik. Suicide in India - A four year retrospective study. Journal of Forensic and Legal Medicine, May 2007, volume 14, issue 4, Pages 185-189.

3. Modi’s Medical Jurisprudence and Toxicology, Twenty first edition

4. Setsuko Fukube, Takahito Hayashi, Yuko Ishida, Hitoshi Kamon, Mariko Kawaguchi, Akihiko Kimura, Toshikazu Kondo. Retrospective study on suicidal cases by sharp force injuries. Journal of Forensic and Legal Medicine, May2008, volume 15(3), issue1, pages163-167.

5. Amanda Burns, Edward Goodall, Tara Moore. A study of suicides in Londonderry, Northern Ireland, for the year period spanning 2000-2005. Journal of Forensic and Legal Medicine, April 2008, volume 15, issue 3, pages 148-157

6. Ê. Stojkoski*, İ. Grozeva. Strategy for Forensic Analysis of Suicidal Cases in Bulgeria. Trakia Journal of science, 2005, Volume 3, Pages 18-20. 